\title{
Larger foraminifera of the Devil's Den and Blue Hole sinkholes, Florida
}

\author{
Laura J. Cotton ${ }^{1,2}$, Wolfgang Eder ${ }^{3}$, and James Floyd ${ }^{1, a}$ \\ ${ }^{1}$ Department of Geological Sciences, University of Florida, 241 Williamson Hall, \\ Gainesville, FL 32611-2120, USA \\ ${ }^{2}$ Florida Museum of Natural History,1659 Museum Road, P.O. Box 117800, University of Florida, \\ Gainesville, FL 32611, USA \\ ${ }^{3}$ University of Vienna, Department of Palaeontology, Althanstrasse 14, 1090 Vienna, Austria \\ apresent address: 7 Sandalwood Drive, Houston, TX 77024, USA \\ Correspondence: Laura J. Cotton (lcotton@ flmnh.ufl.edu)
}

Received: 3 October 2017 - Revised: 23 January 2018 - Accepted: 31 January 2018 - Published: 23 March 2018

\begin{abstract}
Shallow-water carbonate deposits are well-known from the Eocene of the US Gulf Coast and Caribbean. These deposits frequently contain abundant larger benthic foraminifera (LBF). However, whilst integrated stratigraphic studies have helped to refine the timing of LBF overturning events within the Tethys and Indo-Pacific regions with respect to global bio- and chemo-stratigraphic records, little recent work has been carried out in the Americas. The American LBF assemblages are distinctly different from those of Europe and the Indo-Pacific. It is therefore essential that the American bio-province is included in studies of LBF evolution, biodiversity and climate events to understand these processes on a global scale.

Here we present the LBF ranges from two previously unpublished sections spanning 35 and $29 \mathrm{~m}$ of the upper Eocene Ocala limestone, as the early stages of a larger project addressing the taxonomy and biostratigraphy of the LBF of Florida. The study indicates that the lower member of the Ocala limestone may be Bartonian rather than Priabonian in age, with implications for the biostratigraphy of the region. In addition, the study highlights the need for multiple sites to assess the LBF assemblages and fully constrain ranges across Florida and the US Gulf and suggests potential LBF events for future integrated stratigraphic study.
\end{abstract}

\section{Introduction}

Shallow-marine carbonate deposits are well-known from the Eocene of the US Gulf Coast and Caribbean (Frost and Langenheim, 1974; Robinson, 1993; Robinson and Wright, 1993; Donovan et al., 1994; Delgado and Silva, 1997; Randazzo, 1997). These deposits frequently contain abundant larger benthic foraminifera (LBF). The American LBF assemblages, however, are distinctly different to those of Europe and the Indo-Pacific (Adams, 1967, 1983; BouDagherFadel, 2008). Within the Eocene, they lack the huge diversity of Nummulites seen elsewhere (e.g. Schaub, 1981), instead assemblages are often dominated by lepidocyclinids, which do not occur in the rest of the world until at least the upper part of the lower Oligocene (Serra-Kiel et al., 1998; Lunt and Allan, 2004; BouDagher-Fadel, 2008). It is therefore es- sential that the American LBF bio-province is included in studies of LBF evolution, migration and biodiversity, to understand these processes on a global scale. However, this is currently not the case. The inclusion of the Americas to such studies is hampered by a lack of up to date taxonomy and comprehensive biostratigraphy for the region. Numerous detailed taxonomic studies were carried out during the 1950s1970s, most notably by Cole and Vaughan (e.g. Cole, 1938, 1941, 1952, 1958; Vaughan and Cole, 1941). However, little work has been carried out since then, particularly in the Gulf Coast region, which includes the thick Eocene Ocala Limestone, meaning much taxonomy and biostratigraphy requires updating.

Shallow-water carbonate biostratigraphy is often challenging, due to the mutually exclusive environments of LBF and 
planktonic foraminifera and nannofossils, species endemism and migration events. There are currently two main regional biostratigraphic schemes for LBF. Within the European or Tethyan region the Shallow Benthic Zonation (SBZ) of Serra-Kiel et al. (1998) and Cahuzac and Poignant (1997) is used, which was recently updated by Papazzoni et al. (2017). This scheme uses mostly Oppelian zones to form correlations with global stratigraphy (Pignatti and Papazzoni, 2017). Though the scheme is broadly correct and functional, the boundaries between zones often lack exact correlation with global stratigraphic schemes (Pignatti and Papazzoni, 2017), which is problematic when trying to carry out high-resolution studies. There is currently an international effort to further refine this scheme and precisely tie it to global stratigraphy. These studies focus on high-resolution integrated biostratigraphy of sections where LBF are found alongside other microfossils, where there is the potential for chemo- and/or magnetostratigraphy (Cotton and Pearson, 2011; RodríguezPintó et al., 2012; Costa et al., 2013; Cotton et al., 2017; Papazzoni et al., 2017; Pignatti and Papazzoni, 2017). In the Indo-Pacific region, the East Indian letter classification is used to divide the massive shallow-water carbonates of the Cenozoic of that region (Adams, 1965; BouDagher-Fadel and Banner, 1999; McGowran, 2005) and faces a similar set of difficulties. Efforts are also being made in this region to refine stratigraphy, although the massive nature of the shallowwater limestones often precludes the use of planktonic microfossil stratigraphy; instead, $\mathrm{Sr}$ isotopes and bulk stable isotope geochemistry have been employed (Adams, 1967; Renema, 2002; Lunt and Allan, 2004; Cotton et al., 2014).

Currently, within the American LBF bio-province no such comprehensive zonal scheme exists, although many works include biostratigraphic data. Cole and Vaughan published numerous taxonomic works of the LBF, particularly from the Eocene of Florida, Georgia and Alabama (Cole, 1938, 1941, 1958; Vaughan and Cole, 1941). These publications often include detailed stratigraphic ranges and local biostratigraphy alongside their taxonomic and evolutionary observations. A few more recent works have been carried out within the Caribbean: Robinson (2003) published a zonation of the White Limestone Group of Jamaica combining strontium, and planktonic microfossil data with LBF studies; Molina et al. (2016) also carried out a detailed integrated stratigraphy of the Eocene-Oligocene boundary in Cuba. Studies of lepidocyclinid evolution in South America have been carried out by BouDagher-Fadel and Price (2010), BouDagher-Fadel et al. (2010), and de Mello e Sousa et al. (2003). However, the LBF of Florida and other Gulf Coast states have been largely neglected in recent years, with the exception of a few studies such as Bowen-Powell (2010). The taxonomy of the region also requires updating. The nummulitids, in particular have proved problematic, with synonym lists for taxa revealing multiple changes in genus name. Cole (1958), states that several of the Camerina (Nummulites) species may all be one species. This may, in part, be one of the reasons a unified scheme was never published. Current work by Torres-Silva et al. (2018) is utilizing new methods examining the extent to which intraspecific variation occurs in LBF to address some of these taxonomic issues.

Here we present LBF ranges and taxonomic notes from two previously unpublished sink hole sections, Devil's Den and Blue Hole, as a first step in a larger project addressing the taxonomy and biostratigraphy of the LBF of Florida. The two sections represent $35 \mathrm{~m}(115 \mathrm{ft})$ and $29 \mathrm{~m}(95 \mathrm{ft})$ respectively of the upper part of the Eocene Ocala Limestone. This represents a greater vertical expanse of the Ocala Limestone than has been previously described from any other natural outcrop. The two sections are sink holes accessible only through scuba diving. They were sampled in 1962 for the thesis of James Floyd (Floyd, 1962), but the material has since remained unpublished, stored within the collections of the Florida Museum of Natural History (FLMNH), Gainesville, USA. Here we update and reassess the taxonomy of the samples, giving an overview on the biostratigraphy of a rare continuous section through a large part of the Ocala Limestone and provide the initial step of a larger project aiming towards improving the regional biostratigraphy. In addition, we also aim to promote the awareness of the existence of this material in the FLMNH collections, with the potential to contribute to future taxonomic and biostratigraphical studies.

\section{Geological setting}

The Ocala Limestone was first named by Dall (1898) as it outcropped in the region of Ocala, Florida, and was originally considered to be Oligocene age. Cooke (1916) showed that the Ocala Limestone was actually late Eocene age and this has been since generally accepted although various attempts have been made to establish zonations within the Ocala Limestone (Applin and Applin, 1944; Vernon, 1951; Puri, 1957; Scott, 1992). It is the original division into an informal upper and lower member by Applin and Applin (1944) which is in current usage by the Florida Geological Survey (Guy Harley Means, personal communication, 2017).

The Ocala Limestone was deposited during the Eocene, in a tectonically stable period of Florida's history, which spanned from the Cretaceous through the Cenozoic (Salvador, 1991) and allowed thick sedimentary sequences to accumulate. The lithology and fossil content of the Ocala Limestone indicates it was deposited across a carbonate platform which covered much of the Florida Peninsula during this time (Salvador, 1991). The Ocala Limestone is a massive, creamwhite packstone, with some variation in mud content laterally and vertically, varying from a packstone to wackestone. It contains abundant smaller and larger benthic foraminifera but is particularly well known for the latter. Macrofossils of shallow-marine taxa such as echinoids and molluscs are also common (Jones, 1997). 


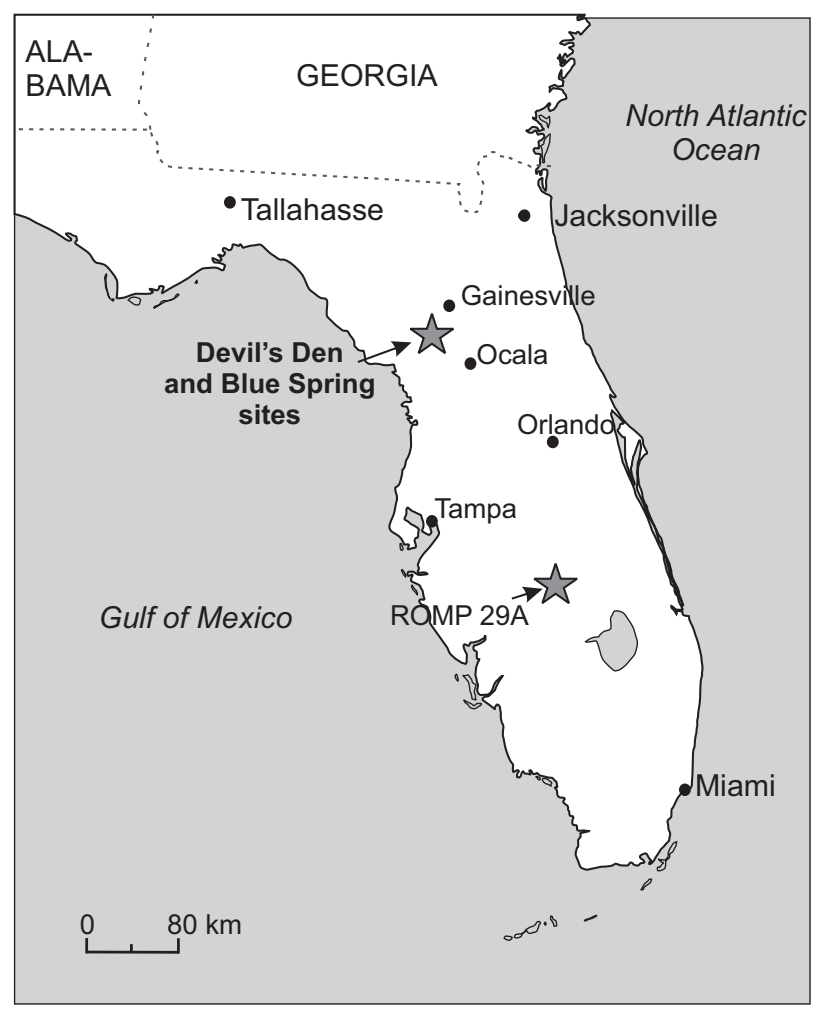

Figure 1. Location map showing Devil's Den and Blue Hole sites. The ROMP 29A core site is also indicated.

\section{Material and methods}

Blue Hole and Devil's Den are located close to the town of Williston, Levy County, Florida (29.38789, -82.486284 WGS 84; 29.407548, -82.476424 WGS 84; see Fig. 1). Devil's Den is approximately $3 \mathrm{~km}$ north-east of Blue Hole. Blue Hole appears to have been renamed the "Blue Grotto" since the original study took place and is now home to the "Blue Grotto Dive Resort". Both sites are sink holes which expose continuous sections of the Ocala Limestone. Samples were taken at approximately $1.5 \mathrm{~m}(5 \mathrm{ft})$ intervals measured from the air-water interface. The samples were taken by scuba diving for the thesis of James Floyd in 1962 and subsequently deposited in the Florida Museum of Natural History; specimen numbers UF 294,015-UF 294,256 (Blue Hole) and UF 294,257-UF 294,543 (Devil's Den). The water was reported as exceptionally clear in both locations during the sampling and allowed for close examination of the wall rock. The maximum depth to which collecting was carried out in each of the sections was limited by physical characteristics of the sinks, making it unsafe to continue further.

Once collected, samples were dried, crushed and sieved through a series of size fractions. Foraminifera were then picked using a paintbrush under a stereoscope microscope. Oriented sections of the LBF from each depth were then prepared as both equatorial and axial sections for species- level identification. A total of $\sim 350$ thin sections were utilized in the study, including both the original thesis slides prepared by James Floyd and additional slides prepared by Laura J. Cotton. Unsectioned specimens were identified to higher taxonomic levels and these are additionally stored within the collections of the FLMNH. Measurements are given from the water level during collection. The original measurements were given in feet; we have converted this to metres but also report the original measurements in brackets for consistency.

\section{Results}

\subsection{Lithology}

The lithology of the sections is taken directly from the observations of James Floyd recorded in his thesis and supplemented by observations of hand specimens. The lithology is relatively homogenous, with slight variation in colour, hardness and foraminiferal content. These variations enable zones to be identified; the boundaries are gradational, meaning there is overlap between the boundary levels given; however, if specimens from the middle of the respective zones are compared, a clear difference can be observed.

Devil's Den is divided into two zones. The uppermost zone extends from $-10.7 \mathrm{~m}(-35 \mathrm{ft})$ to $4.6 \mathrm{~m}(15 \mathrm{ft})$ and consists of white to cream, moderately hard, granular, miliolid limestone. Some tan colours are seen in the open pores. This colouration is irregular and is attributed to staining by groundwater. This is a massive limestone with uneven cementation and local regions of hardening were encountered. The second zone, immediately below, is from approximately $-6.1 \mathrm{~m}(-20 \mathrm{ft})$ to $-11.9 \mathrm{~m}(-39 \mathrm{ft})$ and consists of light grey to cream, hard, granular miliolid limestone. This zone is massive with local recrystallization and cementation producing harder areas. Some tan and cream colours are found in the pore spaces and attributed to staining by groundwater.

Three zones are recognized in the Blue Hole section. Zone I extends from $3 \mathrm{~m}(10 \mathrm{ft})$ to $-7 \mathrm{~m}(-23 \mathrm{ft})$ and consists of light grey to cream or white, moderately hard granular, miliolid limestone. Some local extreme hardening occurs. The surface weathers white and chalky. Some tan colours are seen in pore spaces and are attributed to staining by groundwater. Material from this zone is easily fragmented, due to light cementation. Zone II extends from approximately $-16.8 \mathrm{~m}(-55 \mathrm{ft})$ to $-3.7 \mathrm{~m}(-12 \mathrm{ft})$ and consists of white to light grey, soft, granular, miliolid limestone. This zone is massive with light cementation, permitting the rock to be granulated by rubbing a finger firmly over broken surfaces. The limestone weathers to a soft white chalk. Little recrystallization was found. Zone III extends from $-30 \mathrm{~m}(-95 \mathrm{ft})$ to $-14.3 \mathrm{~m}(-47 \mathrm{ft})$ and consists of white to light grey, moderately hard, granular, miliolid limestone. Some cream to tan colours are present in pore spaces resulting from staining by groundwater. The hardness increases slightly towards the 
bottom of the zone and is irregular and localized, producing dense crystalline nodules which are locally weathered out. A dissolution fissure occurred along a bedding plane at $-18.3 \mathrm{~m}(-60 \mathrm{ft})$.

There is an overall gradual increase in grain size of the matrix from the top to the bottom of both of the sections. Contrary to the studies by Bowen-Powell (2010) and Ward et al. (2003), no mud-dominated facies (e.g, skeletal wackestones and mudstones) have been found in the presented sections.

\subsection{Biostratigraphy}

Ranges and relative abundances of LBF from the two sections are shown in Fig. 2. The larger foraminiferal assemblage is low diversity with a total of seven LBF genera and nine species identified. These include the nummulitids Nummulites, Operculinoides Hanzawa (1935) and Heterostegina d'Orbigny (1826) along with Lepidocyclina Gümbel (1868), Pseudophragmina Douville (1923), Sphaerogypsina Galloway (1933) and Amphistegina d'Orbigny (1826). Miliolids occur throughout, but detailed taxonomy was not carried out. No planktonic foraminifera were found during the analysis; a test sample was analysed for nannofossils (Devil's Den, $-10.5 \mathrm{~m}$ $(-35 \mathrm{ft})$ ); however, they were rare with only placoliths, Reticulofenestra dictyoda and $R$. minuta identified. Independent dating of LBF ranges is therefore not possible at this point.

Nummulites and Operculinoides have ranges spanning the middle parts of the sections. The most commonly occurring nummulitid is Nummulites striatoreticulatus Rutten (1928). The only other Nummulites s.s. species, N. macgillavryi Rutten (1935) with its very easily recognizable large proloculus $(\sim 1 \mathrm{~mm})$, has not been found. Of the genus Operculinoides Hanzawa (1935) the moderately coiled $O$. trinitatensis and the very loosely coiled $O$. ocalanus have been found, although both are much less abundant than $N$. striatoreticulatus. Operculinoides ocalanus (Cushman 1921) has a short range in both sections. The ranges of these three taxa span the middle part of both sections. The most common species of Heterostegina in the section is H. ocalana Cushman (1921), spanning the upper two-thirds of both sections. The second, so far unidentified species, $H$. sp. indet., has a much shorter range in Devil's Den from $-1.5 \mathrm{~m}(-5 \mathrm{ft})$ to $4.6 \mathrm{~m}(15 \mathrm{ft})$ but a similar range to $H$. ocalana in Blue Hole, ranging from $-15.24 \mathrm{~m}(-50 \mathrm{ft})$ to $1.5 \mathrm{~m}(5 \mathrm{ft})$ but with far fewer occurrences. Several representatives of Neolepidina Bronniman (1947) of the $N$. ocalana - macdonaldi group were identified and span the top half of the section at Devil's Den $-10.7 \mathrm{~m}(-35 \mathrm{ft})$ to $4.6 \mathrm{~m}(15 \mathrm{ft})$ and almost the entire section in Blue Hole, making it one of the longest-ranging taxa in the sections. For a more detailed determination of taxa, a morphometric analysis would be necessary. A single species of orthophragmine was also determined - Pseudophragmina fintensis Cushmann (1917) - which has a short-range characterizing the uppermost part of the sections.

In both sections, therefore, there appear to be three broad assemblages from base to top: the miliolid assemblage, the nummulitid assemblage and the Pseudophragmina assemblage. Within the miliolid zone, few LBF are found: only Sphaerogypsina and Amphistegina and, in Blue Hole, Neolepidina. The nummulitid zone is then recognized by the occurrence of $N$. striatoreticulatus, which may also be accompanied by $O$. ocalanus and $O$. trinitatensis and ranges through the mid-part of the sections. Following this the first occurrence of $P$. flintensis then defines the uppermost zone, with no $N$. striatoreticulatus identified and few examples of Operculinoides. Heterostegina and Neolepidina are also both present throughout the two uppermost assemblages of both sites.

\section{Discussion}

\subsection{Biostratigraphy}

The overall assemblage of Devil's Den and Blue Hole is typical of the Ocala Limestone, being mainly comprised of nummulitids and Lepidocyclina. This broadly indicates a mid- to outer platform type setting, also well-known from the Ocala Limestone. The sequence of assemblages may indicate a slight deepening upwards of the site; however, the lithology remains constant and Nephrolepidina is found throughout. No conical foraminifera or associated inner platform assemblage were found in any part of the section, indicating that neither Devil's Den nor Blue Hole extend into the middle Eocene, Avon Park Formation, which lies beneath/below the Ocala Limestone.

Following Applin and Applin (1944) and Applin and Jordan (1945), the upper Ocala is defined by the occurrence of Amphistegina alabamensis, Discocyclina (Asterocyclina) nassauensis, Gypsina (=Sphaerogypsina) globula, Heterostegina ocalana, Lepidocyclina ocalana (=Neolepidina ocalana), Operculina marianensis, O. floridensis (=Operculinoides floridensis), O. ocalanus (=Operculinoides ocalanus), O. willcoxi (= Nummulites striatoreticulatus) and Pseudophragmina citrensis $(=P$. flintensis), the lower part with Amphistegina pinarensis and Camerina aff. C. vanderstoki ( $=N$. striatoreticulatus), and an overall low abundance of foraminifera. The miliolid assemblage zone in the lowermost samples of both Devil's Den and Blue Hole is likely the upper part of the lower member of the Ocala Limestone described by Applin and Applin (1944). The two other assemblage zones, the nummulitid and Pseudophragmina zones, therefore then belong to the upper member of the Ocala Limestone. There is no indication within the LBF taxa that the section extends into the Oligocene. All taxa identified are generally known from the Eocene of the Caribbean and Americas (Cole, 1952; Butterlin, 1981). 
One of the most recent studies of the LBF of the Ocala Limestone is the thesis of Bowen-Powell (2010), who examined the LBF of the Regional Observation and Monitoring Program (ROMP) 29A core. Within the ROMP 29A core, Heterostegina ocalana, Operculinoides (= Nummulites) willcoxi and $N$. striatoreticulatus are the most frequently occurring and long-ranging taxa. This is similar to both the Devil's Den and Blue Hole sections (see Fig. 2), where N. striatoreticulatus and $H$. ocalana are two of the most common taxa. However, O. (N.) willcoxi was not identified in the outcrops (see taxonomic discussion below). There are other differences between the ROMP 29A core and the two outcrops described here; the combined Nummulites (and $\mathrm{Op}$ erculinoides) taxa have a much longer range in the ROMP $29 \mathrm{~A}$ core than in the sections - approximately $70 \mathrm{~m}$ compared with $15 \mathrm{~m}$ in both Devil's Den and Blue Hole. The last occurrence of the genus Nummulites may prove to be a potential tie point for biostratigraphy; however, much more detailed integrated stratigraphy is needed. The range of the lepidocyclinids in the ROMP 29A core is shorter than the range of the nummulitids; however, in Blue Hole the range of the lepidocyclinids spans nearly the entire section and is much longer than that of the nummulitids. Pseudophragmina and Nummulites co-occur within the ROMP 29A core, whilst in the Devil's Den and Blue Hole sections their ranges are successive. However, there is a very apparent increase in the number of occurrences of Pseudophragmina towards the top of ROMP 29A. These similarities suggest that even if slight deepening of the Devil's Den and Blue Hole sites has occurred, it is not a local phenomenon and can be correlated across a significant distance.

The ROMP 29A core itself is much longer than the two outcrop sections described here ( $85 \mathrm{~m}$ compared with $27 \mathrm{~m}$ ) but does not appear to include the lower member of the Ocala Limestone. This suggests that the ROMP 29A core may extend further into the upper Ocala Limestone; alternatively, more likely, given the last occurrences of the Nummulites in both sections, similarities in the assemblage and its location approximately $240 \mathrm{~km}$ south of Devil's Den, it is expanded relative to Devil's Den and Blue Hole. The Ocala Limestone is variable in thickness and is generally thicker further south in the Florida Peninsula. This highlights the importance of using multiple sections across the region to capture the variation in facies, thickness and ranges necessary to create a comprehensive biostratigraphy for the region.

The Ocala Limestone has variously been assigned to the Priabonian and the Bartonian-Priabonian. Whilst we lack true independent dating of the LBF due to the limitations of the section and material, some potential correlations are evident. In both sections there is a clear nummulitid zone, comprising N. striatoreticulatus, Operculinoides trinitatensis and $O$. ocalanus, all of which have a last occurrence relatively close to each other, prior to the top of the sections. These taxa are also known to occur in Cuba, where independent dating of some sections has been possible (Molina et al., 2016; Torres-Silva et al., 2017). Nummulites striatoreticulatus in Cuba occurs consistently from the Lutetian to the lower Priabonian but then decreases in occurrences through the Priabonian. Palaeonummulites trinitatensis also first occurs in the Lutetian and has a last occurrence in the lower Priabonian. Operculinoides ocalanus, however has a younger age with a first occurrence in the uppermost Bartonian and continuing through the Priabonian. Operculinoides ocalanus in the Devil's Den and Blue Hole sections does have a higher first occurrence than the other nummulitid taxa. Heterostegina is known from the uppermost Bartonian of Cuba (Torres-Silva et al., 2017), although it is Heterostegina cubana rather than $H$. ocalana. Species-level determinations of Heterostegina in the Americas have long been problematic, with Cole suggesting only one taxon for the region in the Eocene (Cole, 1957). It is only recently that these determinations have become more resolved (Torres-Silva et al., 2017). The genus, at least, is certainly known from the uppermost Bartonian of the American-Caribbean region. If the Cuban correlations hold true for the US Gulf region, it would suggest that a significant part of the Ocala Limestone is Bartonian in age. This is also supported by molluscan studies: a number of typically Bartonian mollusc taxa have previously been reported from the Ocala Limestone.

The Bartonian-Priabonian boundary is associated with global overturning in a number of microfossil groups, including the LBF (Berggren and Prothero, 1992; Less and Özcan, 2012; Costa et al., 2013). The last occurrence of the largest species of Nummulites ( $N$. millecaput-maximus, $N$. perfortatus-biedai and $N$. gizehensis-lyelli groups), partially defining the SBZ 18/19 boundary, was thought to broadly coincide with the Bartonian-Priabonian transition. However, in a recent integrated study of this event in Armenia by Cotton et al. (2017), it was found the extinction occurred well into the Priabonian. The Priabonian extinctions seen in Cuba, and potentially in Florida, could be linked to this event and warrant further investigation.

\subsection{Taxonomic remarks}

Nummulites in the American bio-province, whilst not as diverse as the genus in Europe and the Indo-Pacific, where several hundred species are recognized, nevertheless have caused significant taxonomic debate. Nummulites willcoxi and $N$. floridensis are two of the most commonly occurring nummulitid species in the American-Caribbean bioprovince apart from Nummulites striatoreticulatus. Nummulites is regarded here as sensu stricto tightly coiled without any, or barely, increasing chamber height in later whorls. The most commonly occurring nummulitid in the sections is Nummulites striatoreticulatus Rutten (1928). The only other Nummulites s.s. species in the American-Caribbean bio-province is N. macgillavryi Rutten (1935); this has an easily recognizable large proloculus $(\sim 1 \mathrm{~mm})$ but was not found in this study. The genus Operculinoides sensu Han- 


\section{DEVIL'S DEN}

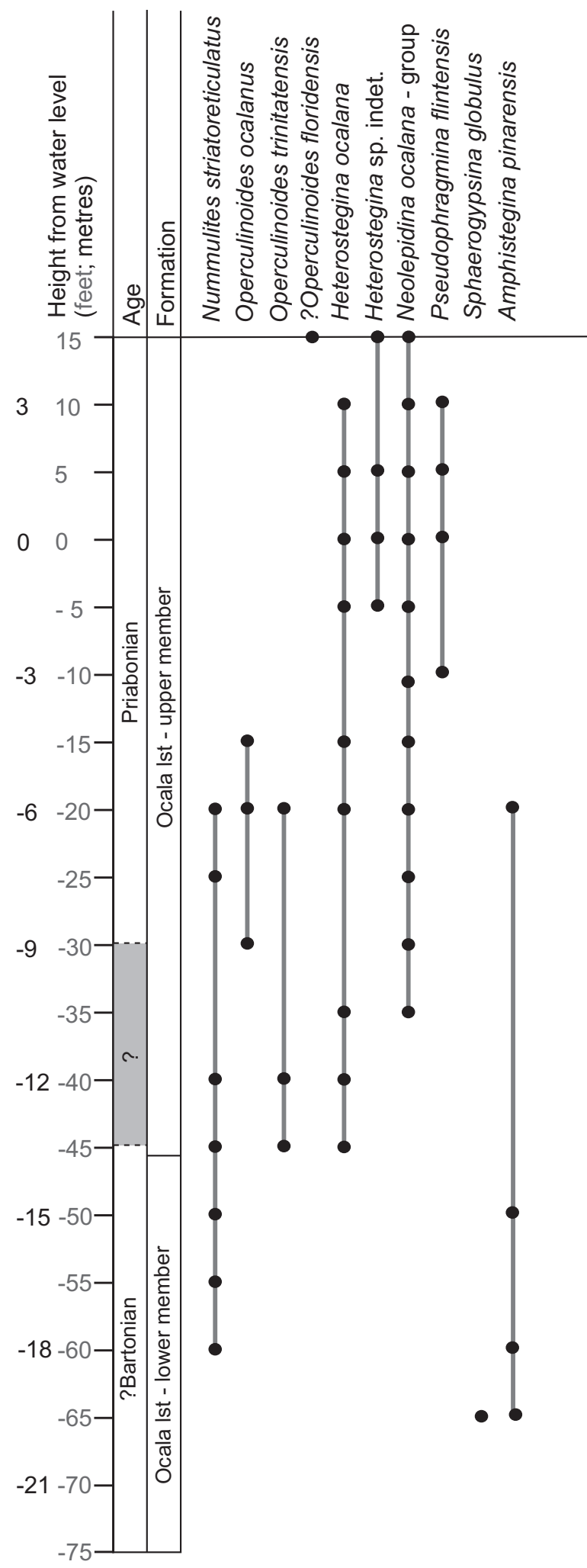

\section{BLUE HOLE}

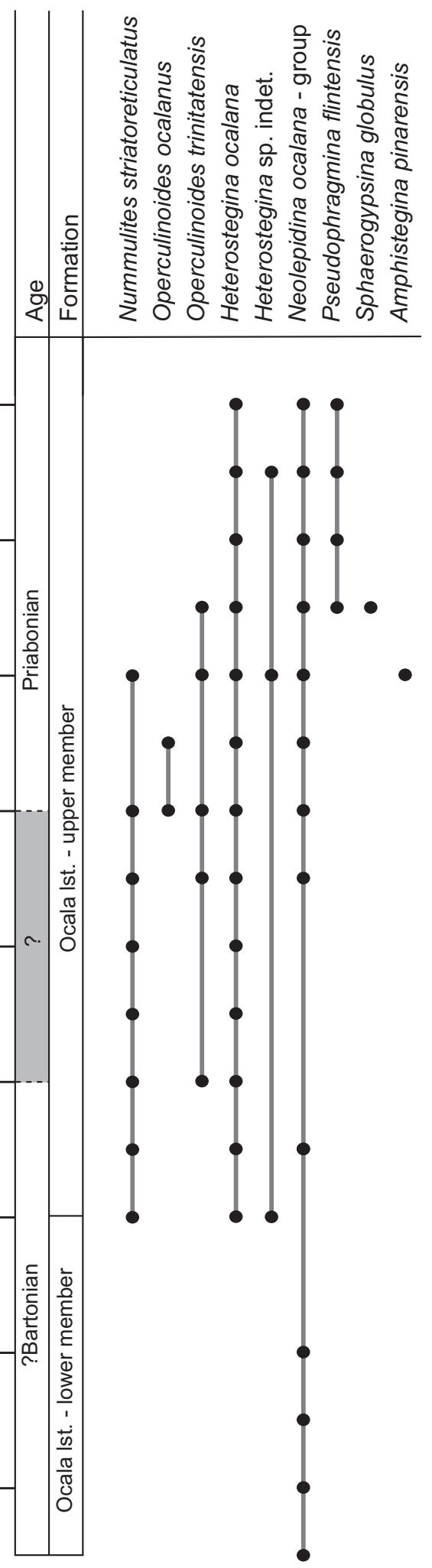

Figure 2. Range chart showing larger benthic foraminifera occurrences in Devil's Den and Blue Hole. Distances are taken from the water level and given in feet and metres. 
(a)

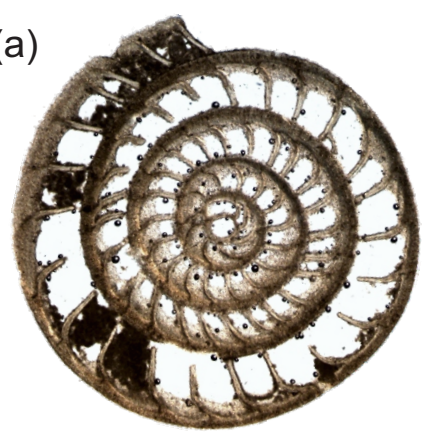

(e)

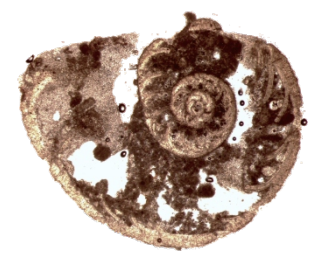

(h)

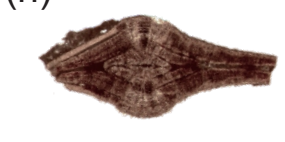

(j)

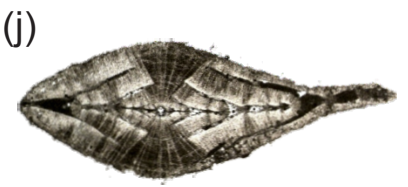

(c)
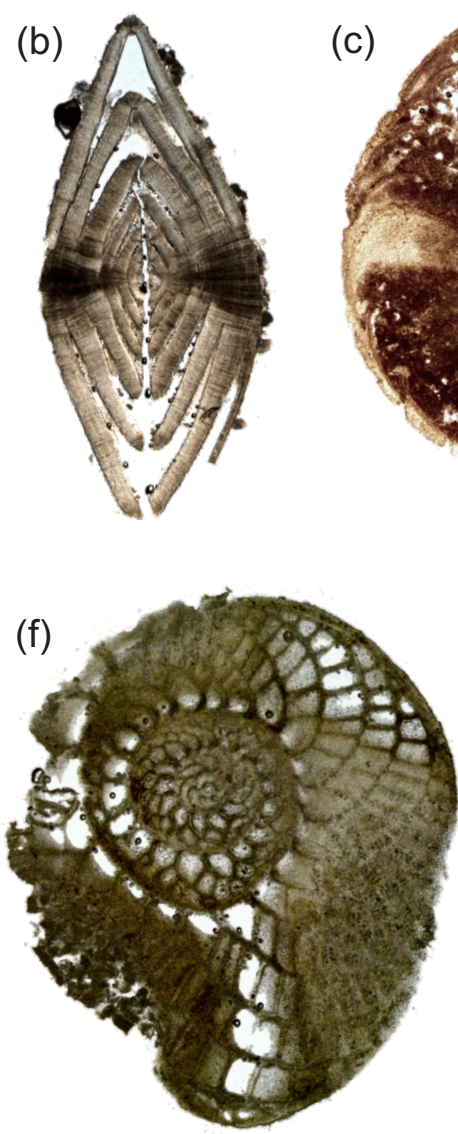

(I)

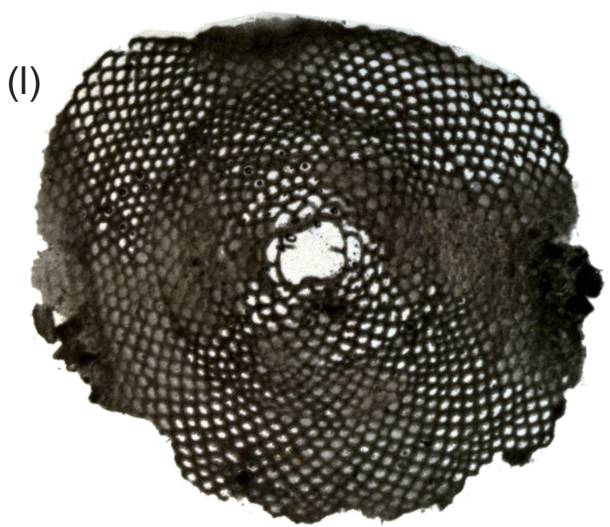

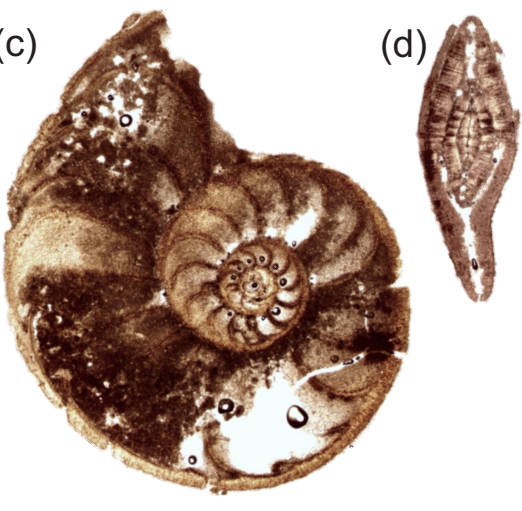

(g)

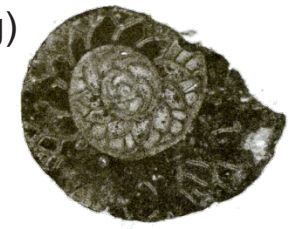

(i)

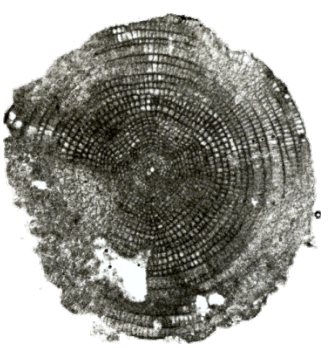

(m)

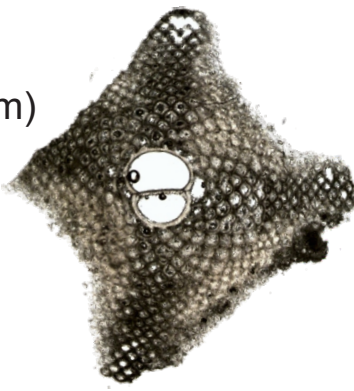

(o)

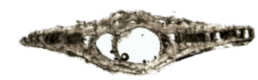

Plate 1. Plate of taxa identified in the study: (a) Nummulites striatoreticulatus equatorial section, Blue Hole $-25 \mathrm{ft}$; (b) Nummulites striatoreticulatus axial section, Devil's Den $-55 \mathrm{ft}$; (c) Operculinoides ocalanus equatorial section, Devil's Den $-15 \mathrm{ft}$; (d) Operculinoides ocalanus axial section, Devil's Den -20 ft; (e) Operculinoides trinitatensis equatorial section, Devil's Den -20 ft; (f) Heterostegina ocalana equatorial section, Devil's Den $-45 \mathrm{ft}$; (g) Heterostegina sp. indet. equatorial section, Devil's Den $-15 \mathrm{ft}$; (h) Operculinoides trinitatensis axial section, Devil's Den - $20 \mathrm{ft}$; (i) Pseudophragmina flintensis equatorial section, Devil's Den - $10 \mathrm{ft}$; (j) Heterostegina ocalana axial section; (k) Amphistegina parvula axial section, Devil's Den -60ft; (l) Nephrolepidina ocalana - macdonaldi group equatorial section, Devil's Den $-5 \mathrm{ft}$; (m) Nephrolepidina ocalana - macdonaldi group equatorial section, Devil's Den - $25 \mathrm{ft}$; (n) Amphistegina parvula equatorial section, Devil's Den -50 ft; (o) Nephrolepidina ocalana - macdonaldi group axial section, Devil's Den -25ft. 
zawa (1935) has been introduced for nummulitids with moderate to strongly exponential coiling in later whorls, with Operculinoides $(N$.) willcoxi as type species. However, due to the missing holotype for $O(N$.) willcoxi Heilprin 1882 (only an unscaled drawing), strongly divergent concepts for this species have been implemented from rather tightly coiled forms similar to $N$. striatoreticulatus (Frost and Langenheim, 1974; Butterlin, 1981) to more loosely coiled forms (Cole, 1941). Of those, the specimen depicted by Barker (1939) resembles the original description the most. This obscurity about the generotype leads to a quite broad definition of the genus Operculinoides, which made Cole (1958) merge Operculinoides into the genus Camerina (=Nummulites). In the present sections two species of Operculinoides occur: the moderately to loosely coiled Operculinoides trinitatensis and the strongly loosely coiled O. ocalanus. Operculinoides willcoxi and O. trinitatensis, though acknowledged as different species in the literature, are very difficult to distinguish, as stated already by Frost and Langenheim (1964) as well as Butterlin (1981). The two most important features for differentiation are the (a) larger size of $O$. willcoxi, which is, however a rather poor separator, and (b) the strong sinusoidal septal shape of $O$. willcoxi as seen in the specimen depicted by Barker (1939). Further, $O$. trinitatensis shows a stronger morphological variability in coiling, from nearly tight to moderately loosely coiled specimens, as can be seen in the depiction of the holotype from Trinidad (Nutall, 1928). While Operculinoides ocalanus has been regarded synonymous with $O$. (N.) floridensis Heilprin (1885) by Cole (1941), Caudri (1996) on the contrary mentions $O$. ocalanus as a discrete taxon. Since the specimens of the presented succession are quite similar to the minor variation described by Barker (1939), with a strong exponential spiral increase and quite broad and high chambers in the last whorls, we regard them as $O$. ocalanus rather than $O$. floridensis. However, it should be noted that one poorly preserved specimen from $4.5 \mathrm{~m}(+15 \mathrm{ft})$ in Devil's Den may be attributed to $O$. floridensis.

Two species of Heterostegina are known from the Eocene of the Americas: Heterostegina ocalana Cushmann (1921) and cubana Cizancourt (1948). Both species were synonymized by Cole (1957), but Torres-Silva et al. (2017) showed that $H$. cubana is morphologically distinct from $H$. ocalana and should be reintroduced. However, of these two species only $H$. ocalana is present in these sections. An additional morphotype of Heterostegina also occurs in these sections. This Heterostegina was initially described as H. panamensis by James Floyd, which would extend the range of this taxon from the middle Oligocene down to upper Eocene age. However, after re-examining the material we believe it is slightly similar to the Heterostegina sp. indet. described by Torres-Silva et al. (2017), especially with regard to coiling and overall chamber shape. $H$. ocalana is the more common of the two "species", while $H$. sp. indet. has a much shorter range and fewer and sporadic occurrences, suggesting that it might be an ecophenotype of $H$. ocalana

Within the Neolepidina group, taxa have been identified as belonging to the $N$. ocalana - macdonaldi group. In general the two taxa are distinguished by $L$. (N.) ocalana being more ornamented and $L$. (N.) macdonaldi being plumper in the lower part; however, the boundaries between the taxa are difficult to determine, and no systematic change appears through the sections. For a more detailed determination of lepidocylinid taxa, a morphometric approach, similar to Bowen-Powell (2010), would be necessary.

\section{Conclusion}

Nine LBF taxa in were identified in Devil's Den and Blue Hole - two of the most extensive, naturally occurring outcrops of the Ocala Limestone. Their ranges indicate that the two sections are comprised of both the upper and lower members of the Ocala, following Applin and Applin (1944), but do not extend into surrounding formations. The LBF comparison with recent work on Cuban material suggests that the lower member and part of the upper member may be Bartonian in age and that the Ocala is not entirely Priabonian as previously suggested. Though independent dating was not possible with this material, the completeness of the sections, and distance from the Bowen-Powell (2010) study give some insight into the consistency of taxa present in the Ocala Limestone and highlights the necessity of combining data from multiple localities to account for facies variation. The lower Priabonian extinctions in Nummulites have tentative links with the global extinctions well-known from this level and therefore may be a strategic focus as a global tie point for future stratigraphic studies.

Data availability. The dataset is the presence/absence of the taxa shown in the results section of the paper; the specimens themselves are housed in the FLMNH collections and are available to researchers upon request by contacting the corresponding author.

Competing interests. The authors declare that they have no conflict of interest.

Acknowledgements. Ana Torres Silva is thanked for her advice on lepidocyclinids and discussions on Cuban stratigraphy. Roger Portell and Harley Means are acknowledged for discussions on the Ocala Limestone. Financial support for this research was provided by Jon L. Thompson and Beverly A. Thompson to Laura J. Cotton. The authors thank Antonino Briguglio and György Less for their constructive comments. This is University of Florida Contribution to Paleobiology 837 .

Edited by: Laia Alegret

Reviewed by: Antonino Briguglio and Less György 


\section{References}

Adams, C. G.: The foraminifera and stratigraphy of the Melinau Limestone, Sarawak, and its importance in Tertiary correlation, Quarterly Journal of the Geological Society, 121, 283-338, 1965.

Adams, C. G.: Tertiary foraminifera in the Tethyan, American and Indo-Pacific provinces, Aspects of Tethyan biogeography, 7 , 195-217, 1967.

Adams, C. G.: Speciation, phylogenesis, tectonism, climate and eustasy: factors in the evolution of Cenozoic larger foraminiferal bioprovinces, The emergence of the Biosphere, 23, 255-289, 1983.

Applin, E. R. and Jordan, L.: Diagnostic foraminifera from subsurface formations in Florida, J. Paleontol., 129-148, 1945.

Applin, P. L. and Applin, E. R.: Regional subsurface stratigraphy and structure of Florida and southern Georgia, AAPG Bull., 28, 1673-1753, 1944.

Barker, R.W.: Species of the foraminiferal family Camerinidae in the Tertiary and Cretaceous of Mexico, Smithsonian Institution, US National Museum, Washington, USA, 1939.

Berggren, W. A. and Prothero, D. R.: Eocene-Oligocene climatic and biotic evolution: an overview, Princeton University Press, Priceton, NJ, USA, 1-28, 1992.

BouDagher-Fadel, M. K.: Evolution and geological significance of larger benthic foraminifera, Elsevier, Amsterdam, the Netherlands, 2008.

BouDagher-Fadel, M. K. and Banner, F. T.: Revision of the stratigraphic significance of the Oligocene-Miocene "Letter-Stages", Revue de Micropaleontologie, 42, 93-97, 1999.

BouDagher-Fadel, M. K. and Price, G. D.: Evolution and paleogeographic distribution of the lepidocyclinids, J. Foramin. Res., 40, 79-108, 2010.

BouDagher-Fadel, M. K., David Price, G. and Koutsoukos, E. A.: Foraminiferal biostratigraphy and paleoenvironments of the Oligocene-Miocene carbonate succession in Campos Basin, southeastern Brazil, Stratigraphy, 7, 283-299, 2010.

Bowen-Powell, J.: Larger foraminiferal biostratigraphy, systematics and paleoenvironments of the Avon Park Formation and Ocala Limestone, Highlands County, Florida, PhD, Florida International University, FL, USA, 2010.

Butterlin, J.: Claves para la determinación de macroforaminíferos de México y del Caribe, del Cretácico Superior al Mioceno Medio, Instituto mexicano del petroleo, Mexico City, Mexico, 1981.

Cahuzac, B. and Poignant, A.: Essai de biozonation de l'OligoMiocène dans les bassins européens à l'aide des grands foraminifères néritiques, B. Soc. Geol. Fr., 168, 155-169, 1997.

Caudri, C.: The larger Foraminifera of Trinidad (West Indies), Eclogae Geol. Helv., 89, 1137-1310, 1996.

Cole, W. S.: Stratigraphy and micropaleontology of two deep wells in Florida, Florida Geological Survey Bulletin, 16, 1-6, 1938.

Cole, W. S.: Stratigraphic and paleontologic studies of wells in Florida: United Brotherhood of Carpenters and Joiners of America, Power House well no. 2, Peninsular Oil and Refining Company's JW Cory no. 1, With description of a species of Foraminifera from another well, Florida Geological Survey Bulletin, 19, 1-94, 1941.
Cole, W. S.: Eocene and Oligocene larger foraminifera from the Panama Canal Zone and vicinity, US Geol Survey Professional Paper, 244, 1-41, 1952.

Cole, W. S.: Late Oligocene Larger Foraminifera from Barro Colorado Island, Panama Canal Zone: (With a Detailed Analysis of American Miogypsinids and Heterosteginids), Bulletins of American Paleontology, 37, 309-338, 1957.

Cole, W. S.: Names of and Variation in Certain American Larger Foraminifera: Particularly the Camerinids, Bulletins of American Paleontology, 38, 256-284, 1958.

Cooke, C. W.: The age of the Ocala Limestone, Washington Government Printing Office Report 2330-7102, 1916.

Costa, E., Garcés, M., López-Blanco, M., Serra-Kiel, J., Bernaola, G., Cabrera, L., and Beamud, E.: The Bartonian-Priabonian marine record of the eastern South Pyrenean foreland basin (NE Spain): a new calibration of the larger foraminifers and calcareous nannofossil biozonation, Geol. Acta., 11, 177-193, 2013.

Cotton, L. J. and Pearson, P. N.: Extinction of larger benthic foraminifera at the Eocene/Oligocene boundary, Palaeogeogr. Palaeocl., 311, 281-296, 2011.

Cotton, L. J., Pearson, P. N., and Renema, W.: Stable isotope stratigraphy and larger benthic foraminiferal extinctions in the Melinau Limestone, Sarawak, J. Asian Earth Sci., 79, 65-71, 2014.

Cotton, L. J., Zakrevskaya, E. Y., van der Boon, A., Asatryan, G., Hayrapetyan, F., Israyelyan, A., Krijgsman, W., Less, G., Monechi, S., Papazzoni, C. A., Pearson, P. N., Razumovskiy, A., Renema, W., Shcherbinina, E., and Wade, B. S.: Integrated stratigraphy of the Priabonian (upper Eocene) Urtsadzor section, Armenia, Newsl. Stratigr., 50, 269-295, 2017.

Dall, W. H.: A Table of the North American Tertiary Horizons, Correlated with One Another and with Those of Western Europe: With Annotations, US Government Printing Office, Washington D.C., USA, 1-26, 1898.

Delgado, D. G. and Silva, A. T.: Sistema paleógeno, Estudios sobre Geología de Cuba, Centro Nacional de Información Geológica, La Habana, Cuba, 115-140, 1997.

de Mello e Sousa, S. H., Fairchild, T. R., and Tibana, P.: Cenozoic biostratigraphy of larger foraminifera from the Foz do Amazonas Basin, Brazil, Micropaleontology, 49, 253-266, 2003.

Donovan, S. K., Jackson, T. A., and University of the West Indies Publishers' Association: Caribbean geology: an introduction, University of the West Indies Publishers' Association, 1289, 1994.

Floyd, J. G.: Stratigraphic distribution of Upper Eocene larger foraminifera from northeastern Levy County, Florida, Masters thesis, University of Florida, Gainesville, FL, USA, 55 pp., 1962.

Frost, S. and Langenheim, R.: Cenozoic reef biofacies, Tertiary larger foraminifera and scleractinian corals from Chiapas, Mexico, Northern Illinois University Press, DeKalb, IL, USA, 1974.

Hanzawa, S.: Some fossil Operculina and Miogypsina from Japan and their stratigraphical significance, International Publishing and Printing Co., Tokyo, Japan, 1-29, 1935.

Jones, D.: The marine invertebrate fossil record of Florida, The Geology of Florida, University Press of Florida, Gainesville, FL, USA, 89-117, 1997.

Less, G. and Özcan, E.: Bartonian-Priabonian larger benthic foraminiferal events in the Western Tethys, Austrian J. Earth Sci., 105, 129-140, 2012. 
Lunt, P. and Allan, T.: Larger foraminifera in Indonesian biostratigraphy, calibrated to isotopic dating, GRDC Museum Workshop on Micropalaeontology, Bandung, Indonesia, 1-30 June 2004, 1-109, 2004.

McGowran, B.: Biostratigraphy: Microfossils and Geological Time, Cambridge University Press, Cambridge, UK, 1-459, 2005.

Molina, E., Torres-Silva, A. I., Ćorić, S., and Briguglio, A.: Integrated biostratigraphy across the Eocene/Oligocene boundary at Noroña, Cuba, and the question of the extinction of orthophragminids, Newsl. Stratigr., 49, 27-40, 2016.

Nuttall, W. L. F.: Tertiary foraminifera from the Naparima region of Trinidad (British West Indies), Geol. Soc. London, Quart. Jour., London, UK, 84, 57-116, 1928.

Papazzoni, C. A., Ćosović, V., Briguglio, A., and Drobne, K.: Towards a calibrated larger foraminifera biostratigraphic zonation: celebrating 18 years of application of shallow benthic zones, PALAIOS, 32, 1-4, https://doi.org/10.2110/palo.2016.043. 2017.

Pignatti, J. and Papazzoni, C. A.: Oppelzones and their heritage in current larger foraminiferal biostratigraphy, Lethaia, 50, 369380, https://doi.org/10.1111/let.12210 2017.

Puri, H. S.: Stratigraphy and zonation of the Ocala Group, Florida Geological Survey Bulletin, 38, 1-248, 1957.

Randazzo, A.: The sedimentary platform of Florida: Mesozoic to Cenozoic, in: The Geology of Florida, University Press of Florida, Gainesville, edited by: Randazzo, A. and Jones, D., University Press of Florida, Gainesville, FL, USA, 39-56, 1997.

Renema, W.: Larger foraminifera as marine environmental indicators, Scripta Geologica, 124, 2002.

Robinson, E.: Some imperforate larger foraminifera from the Paleogene of Jamaica and the Nicaragua Rise, J. Foramin. Res., 23, 47-65, 1993.

Robinson, E.: Zoning the White Limestone Group of Jamaica using larger foraminiferal genera: a review and proposal, Cainozoic research, 3, 39-75, 2003.

Robinson, E. and Wright, R. M.: Jamaican Paleogene larger foraminifera, in: Biostratigraphy of Jamaica, edited by: Wright, R. M. and Robinson, E., Geol. Soc. Am. Mem., 182, 283-345, 1993.

Rodríguez-Pintó, A., Pueyo, E., Serra-Kiel, J., Samsó, J., Barnolas, A., and Pocoví, A.: Lutetian magnetostratigraphic calibration of larger foraminifera zonation (SBZ) in the Southern Pyrenees: The Isuela section, Palaeogeogr. Palaeocl., 333-334, 107-120, 2012.
Salvador, A.: Origin and development of the Gulf of Mexico basin, The gulf of Mexico basin, 389-444, 1991.

Schaub, H.: Nummulites et Assilines de la Tethys Paléogène: taxinomie, phylogénesè et biostratigraphie, Schweizerische Palaeontologische Abhandlungen, Birkhäuser, Basel, Switzerland, 104, 1-238, 1981.

Scott, T. M.: A geological overview of Florida, Open File Report No. 50, 1-78, 1992.

Serra-Kiel, J., Hottinger, L., Caus, E., Drobne, K., Ferrandez, C., Jauhri, A. K., Less, G., Pavlovec, R., Pignatti, J., Samso, J. M., Schaub, H., Sirel, E., Strougo, A., Tambareau, Y., Tosquella, J., and Zakrevskaya, E.: Larger foraminiferal biostratigraphy of the Tethyan Paleocene and Eocene, B. Soc. Geol. Fr., 169, 281-299, 1998.

Torres-Silva, A. I., Hohenegger, J., Ćorić, S., Briguglio, A., and Eder, W.: Biostratigraphy and evolutionary tendencies of Eocene heterostegines in western and central Cuba based on morphometric analyses, PALAIOS, 32, 44-60, 2017.

Torres-Silva, A. I., Eder, W., Hohenegger, J., and Brigugliom A.: Morphometric analysis of Eocene nummulitids in western and central Cuba: taxonomy, biostratigraphy and evolutionary trends, J. Syst. Palaeontol., https://doi.org/10.1080/14772019.2018.1446462, in press, 2018.

Vaughan, T. W. and Cole, W. S.: Preliminary report on the Cretaceous and Tertiary larger foraminifera of Trinidad British West Indies, Geol. S. Am. S., 30, 1-85, 1941.

Vernon, R. O.: Geology of Citrus and Levy Counties, Florida, Florida Geological Survey Bulletin, 33, 1-256,1951.

Ward, W. C., Cunningham, K. J., Renken, R. A., Wacker, M. A., and Carlson, J. I.: Sequence-stratigraphic analysis of the Regional Observation Monitoring Program (ROMP) 29A test corehole and its relation to carbonate porosity and regional transmissivity in the Floridan aquifer system, Highlands County, Florida, US Geological Survey Open-File Report, 03-201, 2003. 